This is a pre-copy-editing, author-produced PDF of an article accepted for publication in Social History of Medicine following peer review. The definitive publisher-authenticated version, 14:1 Social History of Medicine (2001) 107-131, is available online at http://shm.oxfordjournals.org/content/14/1/107.full

\title{
Legal Madness in the Nineteenth Century
}

by Peter Bartlett*

\section{The Social Histories of Madness, Law, and Medicine}

Wherever there is law, there is madness. Wherever there are legal relations between people, there is a legal issue as to how those relations are affected by the insanity of one of the parties. Legal treatises contain no shortage of cases regarding capacity to make wills, to marry, to sign contracts, to testify in court, to engage in criminal or civil litigation, or to be convicted of a crime. Similarly, wherever there is madness, law is usually close by. The crown's jurisdiction over the estates and persons of lunatics and idiots had been codified by the early fourteenth century, ${ }^{1}$ and seems to have existed considerably earlier. ${ }^{2}$ Confinement of the insane has never been simply a medical matter: doctors have always been required to apply criteria and processes defined by law. The mad-doctors themselves, like other doctors and health care workers, have been subject to legal regulations which define standards of practice.

Historians of madness have become increasingly adventurous in their approaches and in the documents upon which they have relied in their work. Nonetheless, legal sources have tended to be under-exploited. Where they are used, they are sometimes not understood in their legal context, a context which may lead to clues or insights regarding interpretation. This article is intended to alert historians of madness to the variety of legal 
sources, and the ways in which they may assist scholars in their researches.

The social history of madness can no longer be equated (if it ever could) to the histories of doctoring and of medical science. It now also includes the study of the experiences of the mad, the broader public understanding of insanity, and the array of social systems and power structures through which society controls and comprehends the individuals, and in which the mad individual negotiates day-to-day life. In this relatively broad understanding of the social history of madness, the relevance of legal sources is clear. At the most fundamental level, law determines the rights of the insane person. A finding that an individual lacks capacity to contract, for example, removes the authority of the individual to make fundamental decisions about his or her day-to-day life, such as how he or she will conduct their business affairs. A finding of unfitness to plead in a criminal matter placed individuals in a legal limbo, subject to confinement without a finding of guilt, but unable to clear their name by challenging their accusers. ${ }^{3}$ Civil confinement, of course, resulted in the physical detention of the individual. The law might thus be very much a part of the life of the insane person, and an understanding of the dynamic between the individual and the law is pivotal to understanding the life of the insane person. ${ }^{4}$

The law of madness is interesting to historians not merely because of the direct effect it has on the lives of insane people. It also provides a way in which society conceived madness which may be juxtaposed to that of medical professionals. At the centre of traditional medical discourse are the concepts of disease and diagnosis, and the objective of the medical profession has long been cure or, at least, care. This is as true of the history of psychiatric medicine as of any other branch: the medical causes of insanity have long been a matter of medical debate, and the relationship between patient and doctor has been characterized as one of cure and care. Pivotal to the legal discourse are instead the protection of society, and whether individuals are responsible for 
themselves and their actions. Thus the legal contexts noted above, with the exception of civil confinement, can be understood as variations on the theme of capacity determination, essentially a decision as to whether individuals can be held responsible for their decisions. Civil confinement indicates the other legal priority. At common law, confinement was determined on the basis of dangerousness. ${ }^{5}$ Clearly in application, there is overlap between the legal and medical objectives. If individuals lack capacity or are dangerous to themselves or others, the question arises as to what to do with them. Here, the legal system has long looked to establish systems of care, suggesting a point of connection with the medical objectives. Nonetheless, the approaches are at their core quite different.

The differences are not merely a matter of professional emphasis. They extend to the basic understanding of madness. In law, insanity was not a state of being or subsisting condition, analogous to a disease. English law had nothing which corresponded to 'judicial personhood' in continental legal systems. ${ }^{6}$ Instead, English law compartmentalized insanity. For English law, insanity was not intrinsic to the individual, but was determined by the abilities of the individual in the context of the specific situation. Thus for admission to an asylum, the statutes required it to be shown that an individual was 'a proper person to be taken charge of and detained under care and treatment'. ${ }^{7}$ Compare this to the following test, used in 1870 to determine the validity of a will:

It is essential to the exercise of such a power that a testator shall understand the nature of the act and its effects; shall understand the extent of the property of which he is disposing; shall be able to comprehend and appreciate the claims to which he ought to give effect and, with a view to the latter object, that no disorder of mind shall poison his affections, pervert his sense of right, or prevent 
the exercise of his natural faculties- that no insane delusion shall influence his will in disposing of his property and bring about a disposal of it which, if the mind had been sound, would not have been made. ${ }^{8}$

Various consequences of interest to historians of madness flow from this approach of compartmentalisation.

First, as a pragmatic matter of understanding the lives of the insane, it is and has always been procedurally very difficult to lose all rights at law. For example, confinement in an institution did not necessarily preclude an individual from making a valid will or an enforceable contract. This is significant not merely for understanding the rights and legal status of the subject; it also places a particular dynamic on the relationship of care. Since law did not deprive insane individuals of all rights, extra-legal control mechanisms such as surveillance or controlling access to the mad person might be particularly important to ensure their safety and appropriate conduct. ${ }^{9}$

Second, since insanity in law is bound up with a specific factual situation, legal determinations of insanity and incapacity require narration of those relevant factual contexts. In some cases, such as major competency determinations, these narrations can be quite extensive. The test of testamentary incapacity cited above gives some indication of the scope of evidence to be considered. Clearly, the range of property of the individual was relevant; but equally important would be the relations with the presumed heirs, and whether any animosity was the result of a deluded imagination or instead an appropriate response to the heirs' waywardness or cruelty. The court reports can thus provide considerable information as to the day-to-day situation of the alleged mad person. ${ }^{10}$

Care is appropriate to the use of the documents in this way, however. The criteria applied by the courts reflected the substantive law in question, and just as the medical history of insanity is bound up with the practical history of doctoring, 
so the legal history of insanity cannot be divorced from the broader history of law. Cases regarding competency to contract, for example, provide specific insight into the sort of rationality seen to be required for contract law and, by extension, the conceptualization not merely of insanity but also of contract law itself. That provides interesting possibilities for research into the history of contract law, but, for the historian of madness, care is required. The law also had policies of varying formality as to how closely it would scrutinize decisions. In Evans v. Knight and Moore, ${ }^{11}$ for example, it was held that the degree of evidence necessary to establish testamentary capacity varied according to whether the will 'gave effect to probable intentions'. In that case, the will was 'precisely such a disposition as natural affection would dictate', ${ }^{12}$ and testamentary capacity was found notwithstanding rather weak evidence. It is at least arguable that this sort of result-oriented approach may colour the presentation of the facts in the narrative, and scholars should not approach these texts more naively than they would any other source of the period.

While the history of madness can no longer be reduced to the history of medical practice, medicine is still of course understood as particularly relevant to the history of insanity. Here, too, legal sources have much to offer. Law has not remained static over the last near-millennium, and it of course has been influenced by medical knowledge, particularly in the last two hundred years. For that same period, the appearance of psychiatrists as expert witnesses was arguably a strategy to enhance professional reputation. This suggests pressure on doctors to re-formulate their ideas in a way which would be comprehensible to the legal system. ${ }^{13}$ Insofar as that process of re-formulation affected not merely court testimony, but also the doctor's daily medical practice, law can be seen as influencing medicine. Certainly, the theoretical bases of law and medicine may have been different, but as Smith ${ }^{14}$ and Fennell ${ }^{15}$ have shown, law and medicine had their communal interests and approaches, as well as their differences. Legal 
and medical doctrines regarding insanity are thus not merely open to juxtaposition; they are also a source of mutual influence.

The importance of law to medical practice can be considered in both structural and substantive terms. The former extends beyond defining the forms needed for confinement of an individual, for example, although it certainly includes that. Law also has a role in structuring the relationships among a wide variety of actors: doctors, patients, judges, nurses, and health administrators. In modern times, we know of the frustration of some psychiatrists at what they perceive as over-zealous legalism, law restricting their ability to do their job. This response is not restricted to the late twentieth century, and the tensions among different professions were very much part of the nineteenth and early twentieth century as well. ${ }^{16}$ Law provides the process in which the actors and discourses interact, most visibly in court, but in fact whenever regulation comes into play.

A variety of possibilities open to the historian. Some of these involve mining the records for factual information. For example, routine diagnosis of insanity appears to be understudied by medical historians. ${ }^{17}$ This may in part flow from the relatively haphazard practices of nineteenth-century medical record-keeping. By comparison, at least some sets of legal records are comprehensive and consistent in format: by law, all patients admitted to an asylum were described in one or more medical reports prior to admission and, at least after 1845, by the asylum superintendent in the asylum case book. ${ }^{18}$ These documents contain discussions of what symptoms led a medical man to reach particular diagnoses, and potentially provide valuable insights into the day-to-day business of diagnosis.

Similarly, legal documents may cast further light on a internalist medical debates. For example, a number of cases relating to the determination of civil capacity reflected the broader medical debate regarding the acceptance of partial insanity, monomania and moral insanity as diagnostic 
categories. ${ }^{19}$ These are cases in which not merely legal, but also medical concepts were debated, and they thus offer potential insights into the history of those medical concepts. While legal documents can certainly be of assistance in examining such questions, some care must be taken in this sort of analysis, for the pursuit of the legal process may also have substantive effects. The completion of an admission document for an asylum, or the swearing of an affidavit attesting to the incapacity of a testator, require doctors to justify and thus to reflect on what they are doing differently than would be the case for diagnoses outside the legal arena. The scrutiny of the documents by others might result in more care being taken, resulting perhaps in different weighting of diagnostic factors, or indeed different factors being considered altogether, than would be the case in a more private doctor-patient relationship. Further, the legal record will record what the doctor believes will be relevant to the legal process. This leads to a more abstract question, of potential interest to medical and legal historians alike: do the legal and medical systems characterize problems in the same way, and if not, what does this tell us about both medicine and law? The legal document becomes, not merely a record of medical diagnosis, but also a record of how the doctor plays out his (or perhaps, in the twentieth century, her) role in the legal system.

The tension, or the synthesis, or the dynamic creation between legal and medical theoretical frameworks is embodied in the doctor's legal role, and will be reflected in the document the doctor creates. The influence of various factual, political, professional and ideological factors is appropriately the subject of historical debate in specific cases. Relative influence of these factors may depend for example on the novelty of the medical and legal practice recorded in the document, the legal context, the experience of the doctor, and the facts of the individual case. The relationship between law and medicine here must be perceived as dynamic: the involvement of the doctors in the legal system affects the practices of both medicine and law. The various 
classes of documents identified below should thus not be considered as simply medical or alternatively legal. Any document required by law to be kept will have a legal orientation, and any document where a medical person expresses professional views will have a medical orientation. The importance is to understand the interface.

Notwithstanding its relevance, the legal context has been left largely unexamined in the history of madness. There are studies particularly relating to criminal insanity and how doctors fared in the criminal courtroom, ${ }^{20}$ and there is a burgeoning literature on confinement in asylums. ${ }^{21}$ There has however been little attention paid to the use of medical testimony in cases of competency determination in civil law contexts such as wills, contracts, or marriage. Nor have historians registered particular interest in tort liability for causing 'nervous shock', ${ }^{22}$ or in the willingness of the courts to award damages for mental illness when caused by physical injury. Only some of the legal structures developed to deal with the mentally vulnerable and the mad involved the medical profession. Scholars have not addressed issues such as why medical testimony became common in cases of testamentary capacity, but not in cases of non est factum ${ }^{23}$ or undue influence even though these cases involved similar sorts of people. While potentially instructive to understand the relative roles of law and medicine, these failures to crossfertilize are as yet largely unexplored.

All of these issues contributed to the understanding of insanity in the nineteenth and twentieth centuries, and all are ripe for historical research. 'Lunatics', 'idiots', and the 'feeble-minded' appeared in all the courts of the land, with a wide variety of legal problems. The scope for research is therefore immense. On some issues, such as tort liability, so little research has been done that it is not even clear what sets of documents remain, or what they would reveal.

of necessity, this article cannot deal in any depth with the breadth of material available, and I do not claim to have expertise in all legal records of all courts. What follows are 
comments related specifically to the legal history of madness, intended to assist newcomers to make sense of the field. First, various general sources of broad application are identified. Then three specific areas are discussed: criminal insanity, findings of civil incompetency, and civil confinement.

\section{General Sources}

The intricacies of law seem to pose a psychological barrier to medical historians. They should not, since they are rarely as difficult as they appear at first blush.

Nonetheless, access to a good text to explain both processes and doctrine is likely to be extremely helpful. A plethora of these were written in the nineteenth century. A few helpful manuals are listed in appendix I to this article.

While the varieties of legal document are legion, most legal research will at some point involve reference to reported case law- the published reasons of judges in deciding particular cases. A brief note as to how to locate this may be of assistance. Legal citations are of a relatively standard form, containing the name of the case (usually underlined or in italics), its year, ${ }^{24}$ the volume number of the report, the name of the report (usually abbreviated), ${ }^{25}$ and the page reference. Occasionally, the court which decided the case is also included in parentheses at the end of the cite. If the case is reported in a number of places, several citations may be given.

Prior to the mid-1860s, case reports were published privately, and known by the person supervising the compilation of the collection. Case reports that are the names of people are of this type. Many, but not all, of these have been combined together in one set of case reports, the English Reports. Some of the reports compiled contain some quite early cases. Bellewe, for example, contains cases from 1378 to 1400, and Jenkins from 1220 to 1623. That said, the vast bulk of the cases date from the seventeenth to the mid-nineteenth centuries, and this set of reports is the most important source 
of printed case law for this period. The English Reports run to 176 large volumes plus a two-volume index. They will be contained in any good law library, and have also been published on CD-ROM.

In part because some libraries still have copies of the uncompiled reports, the tradition is that cases in these volumes are still cited by the original named series, not by their volume and page in the English Reports. ${ }^{26}$ A full list of the reports included in the English Reports can be found at the beginning of the first volume, or, usually, on a wall chart located near the reports in the library. This list will also show which volumes contain which named series of reports. Since 1865, an official set of law reports has been published. These official reports include the Weekly Law Reports, Appeal Cases, Queen's Bench Reports, ${ }^{27}$ Admiralty and Probate Reports (to 1971), Family Reports (from 1972), Chancery Reports, Exchequer Reports (to 1880) and Common Pleas Reports (to 1880). They will again be contained in any good law library, and have also been published on CD-ROM. They are all indexed together, in the so-called 'red' index.

The introduction of the official law reports did not, however, mean that private law reporting ceased. The medical historian may encounter references to a number of these, including the All England Reports, the Law Journal (Magistrates' Cases), the Law Times Reports, Cox's Criminal Cases, and the Justice of the Peace Reports. While many of these are routinely available in all good law libraries, some private reports are not as readily available, so a certain amount of travel may be necessary.

A word of warning is appropriate. Only a small minority of cases are reported. Historically, jury trials are almost always not reported in traditional case reports (although appeals may be). Case reports after all contain reasons for judgment, and juries, unlike judges, do not provide reasons for their decisions. This is particularly problematic in the criminal sphere, where jury trials predominate. These trials might, of course, be reported in considerable detail in the 
regular newspapers, and the Times has historically been the newspaper referred to by lawyers in this regard. Even for civil cases, only a small minority of cases are reported, and it is unlikely to be a statistically balanced sample. The economics of litigation mean that reported case law is likely to concern predominantly wealthy parties. The impact of law on other classes is less likely to appear in this source. In addition, the cases reported are those of interest to lawyers of the period, generally because of their relevance in setting new legal precedent. The fact that they are precedent-making may well indicate that they were factually or legally unusual: it cannot be assumed that they are 'typical' of anything.

While much of the law regarding competency, tort liability, and criminal insanity is based in case law, statutes were also important, particularly those regarding committal in asylums and madhouses and matters of procedure. Any good law library should have a complete run of statutes, organized chronologically. Particularly significant statutes relating to idiocy, lunacy or mental deficiency will be mentioned in the general legal treatises in appendix I. The 1957 Report of the Royal Commission on the Law Relating to Mental Illness and Mental Deficiency ${ }^{28}$ also contains a reasonable introduction to prior legislation. Statutory consolidations can further be of assistance, both because they contain all the major statutes in one place, and because they contain important segments from otherwise unrelated legislation. For the nineteenth century, the consolidation by Danby Fry $^{29}$ is particularly helpful.

\section{Criminal Insanity}

The treatment of the insane under criminal law is the one area where the history of law and madness has a large and diverse literature. I will make no attempt here to summarize this literature, which tends to concern the development of the defence of insanity. The first volume of Nigel Walker's Crime and Insanity in England ${ }^{30}$ provides the beginning researcher with

a good starting point on the development of the law. 
Insanity arose in the criminal context in three situations: fitness to plead, the defence of insanity, and the detention of insane prisoners. The first of these situations relates to competence to conduct a defence, rather than ultimate responsibility for the crime. By 1800, at both common law and by statute, a person found unfit to plead was not permitted to be tried, but was instead kept in strict custody 'until His Majesty's pleasure be known'. 31 The classic test to be applied is drawn from Baron Alderson's charge to the jury in R. v. Pritchard:

whether he [the accused] is of sufficient intellect to comprehend the course of proceedings on the trial, so as to make a proper defence - to know that he might challenge any of you to whom he may object and to comprehend the details of the evidence, which in a case of this nature must constitute a minute investigation. ${ }^{32}$

This legal threshhold has remained remarkably stable since 1836, when that statement was made.

If the accused were fit to plead, insanity might still provide a substantive defence to the charge. It is this stage that has provoked most scholarly interest. The insanity defence was formalized by statute in 1800,33 but the statute did not establish an actual test of insanity for purposes of the defence. Was the test simply that accused persons not understand that their actions were wrong? Or illegal? What if they were deluded into believing their actions were producing a public benefit, or redressing a supposed grievance or injury? What if the accused acted on what medical testimony indicated was an irresistible impulse? Those questions were legally settled by McNaughten's Case in 1843, ${ }^{34}$ when the court set the standard which continues to apply:

...it must be clearly proved that, at the time of the committing of the act, the party accused was 
labouring under such a defect of reason, from disease of the mind, as not to know the nature and quality of the act he was doing; or if he did know it, that he did not know he was doing what was wrong. ... If the accused was conscious that the act was one which he ought not to do, and if that act was at the same time contrary to the law of the land, he is punishable. ${ }^{35}$

Irresistible impulse, the test generally preferred by the nineteenth-century medical professionals, remained in scotland as a plea in mitigation of sentence, but not south of the border. ${ }^{36}$ It was not until 1957 that a form of this test was adopted into English 1 aw, ${ }^{37}$ and then it was restricted to cases of murder, where the plea resulted in a reduction of the charge to voluntary manslaughter. The relatively narrow definition contained in McNaughten's Case was not in line with medical thinking, and gave rise to considerable debate in the nineteenth century. The result has been a corpus of work examining the interrelations between legal and medical conceptions of insanity and criminal law. ${ }^{38}$

Individuals found unfit to plead or not guilty by reason of insanity were detained 'until his Majesty's pleasure be known'. That was likely to mean a long-term committal. Until 1863, the place of detention was likely to be the local county asylum or, occasionally, Bethlem. ${ }^{39}$ When the new asylum at Broadmoor opened in 1863, it took the bulk of criminal lunatics. Records of these institutions often continue to exist. The actual warrants used to commit these individuals in the nineteenth century are relatively pro forma, although case books and other asylum sources can sometimes contain more detailed and specific information regarding the individuals and their circumstances. ${ }^{40}$

From this it will be clear that issues of insanity could occur throughout the criminal justice system. The difficulty for the historian is that criminal proceedings tend to be oral, and juries leave no records as to their deliberations. Useful records are therefore few. Indictments (statements of the 
charge), trial calendars (which will normally include verdicts), and gaol records may allow the tracking of individuals through the system, but they are not likely to provide detailed notes of evidence. For that, reliance on secondary accounts, such as those contained in newspapers, will be necessary. Here, particular mention should be made of the old Bailey Sessions Papers. These are accounts of trials at the Old Bailey (the central Criminal Court for London), starting in the early eighteenth century and continuing into the twentieth. Virtually all trials ${ }^{41}$ are reported, with verbatim accounts of witness statements. These accounts have already been used by Joel Eigen in his work on eighteenthcentury insanity cases, and those wishing to use this source should consult his work. ${ }^{42}$

\section{Findings of Civil Competency}

Study of the determination of civil competency has been marginal in the history of modern law and madness to the point of being almost ignored. Competency determinations through the use of the Royal Prerogative power were formalized by the beginning of the fourteenth century, ${ }^{43}$ thus well before civil or criminal confinements. Other issues of civil competency were pervasive in the court system, and included questions of competence of witnesses to testify or parties to undertake proceedings, of testators to make a valid will, and of parties to make a valid contract. Very little has been written regarding the history of these procedures, although a general introduction to English practice can be found in the Final Report of the Ontario Enquiry on Mental Competency. ${ }^{44}$

A perusal of reported case law would suggest that the field is also rife with material of interest to historians generally, and social, legal and medical historians in particular. Rules for competency determination were undergoing substantial revision in the nineteenth century. Older categorizations were disappearing. Eighteenth-century courts had been resistant to finding incompetence where, for example, 
the infirmity was the result of advanced age. ${ }^{45}$ This reluctance was giving way by the beginning of the nineteenth century. ${ }^{46}$ Similarly, the requirement for a finding of idiocy that the individual's condition had to originate at or very near birth ceased by the mid-nineteenth century to be required as a matter of law. ${ }^{47}$ For lunacy, the progression of the nineteenth century shows a move away from the delusion as the sine qua non of incompetency, ${ }^{48}$ towards a more functional approach: could the individual, as a matter of practicality, make the decision required of them? ${ }^{49}$

Existing research does not address the degree to which these changes were a result of pressures from within the legal system, from the broader socio-economic system, or from medical professionalisation. The move towards a functional test of competency could perhaps be portrayed as a response to the needs of the broader economic system, and on its face does not suggest a more medicalized approach. At the same time, medical evidence appears to be increasingly common in these cases, and medical debates and developments are reflected in the case law. For example, the move in the case law away from the understanding of idiocy as a condition beginning at or near birth corresponds to a similar movement in the medical literature, where symptoms similar to idiocy ceased to be understood as necessarily originating at birth. ${ }^{50}$ The political situation was also changing, however. An early reluctance of courts to find an individual an idiot under the Royal Prerogative power may well have flowed from the fact that, in such a situation, the crown would keep the profits of the idiot's land. A lunacy finding, by comparison, would require the profits to be passed on to the lunatic or his or her heirs upon termination of the Crown's control. The demise of the financial interest of the crown following the English revolution removed any financial influence upon the court's finding .

In legal practice, and for discussion of the mechanics of research, the determination of civil competence may conveniently be divided into two aspects. First, there was the 
Royal Prerogative power, a process by which individuals could be declared to be an idiot or lunatic, and their common law rights restricted. Secondly, issues of competency could be raised in specific litigation, most frequently on the question of whether an individual was competent to execute a will or contract. While the same sorts of factual situation fell to be determined under both procedures, they were completely separate processes, governed by separate legal structures. While the issue under the former procedure was expressly the lunacy or idiocy of the individual, the issue under the latter was whether the will was valid or the contract enforceable. The former was heard by specific administrative officials. By the mid-nineteenth century, a considerable statutory basis had developed for its procedures. The forum for the latter was determined by the type of action at issue - almost always a trial - and was governed almost exclusively by precedent rather than statute.

\subsection{The Royal Prerogative Power}

The Royal Prerogative power (also called issuing a Commission in Lunacy or being found lunatic or idiot 'by inquisition') was the closest England came to a general finding of insanity. In its mediaeval origins, it had the effect of making the subject, called the 'lunatic so found', a ward of the crown and delivering his or her estate into the control of the King. ${ }^{51}$ By the nineteenth century, with developments in other areas of the law of insanity, it could no longer be considered to have such a global effect. Thus while the Prerogative could in theory give the crown control not merely of the estate, but also of the person of the lunatic or idiot, ${ }^{52}$ the nineteenth-century statutes indicate that documents allowing committal to madhouses still had to be completed if the individual had been found lunatic by inquisition. ${ }^{53}$ Similarly, while an order under the Royal Prerogative power prior to the execution of a will raised a presumption of testamentary incapacity, it did not preclude a trial of the 
issue. ${ }^{54}$ Even in the law of contract, the effect of the Commission was dubious until 1904 on the question of whether a contract signed by the subject during a 'lucid interval' was valid. ${ }^{55}$

The power to exercise the Royal Prerogative was awarded by each monarch upon ascension to the throne. Following the demise of the Court of Wards in the seventeenth century, ${ }^{56}$ the convention was to give it to the Lord Chancellor. ${ }^{57}$ By the beginning of the nineteenth century, his role appears to have been essentially administrative. The actual conduct of the inquisition was entrusted to Masters in Lunacy (before 1845 called Commissioners in Lunacy), ${ }^{58}$ officials appointed by the Lord Chancellor. Up to 1842, the Masters were judges; after that time they were barristers of at least ten years standing. ${ }^{59}$ Before 1833, the proceedings were under the control of three of these officials; after 1833, one official had control of the inquisition. ${ }^{60}$ If the alleged lunatic or idiot requested a jury trial, that would mean empannelling a jury and hearing evidence, orally or in writing. If no such request were made by the subject of the inquiry, the Master could after 1853 determine the matter without a jury. ${ }^{61}$

The guide to the Public Record Office indicates that, up to 1874, the Masters were a part of the Petty Bag Office, a division which also dealt with admission of solicitors to practice and bankruptcy. At that time, they became a part of the Chancery division directly. Under the 1890 legislation, they became a part of the Management and Estates Division of the Supreme Court of Judicature. They were then incorporated into the court of Protection when that court was founded in 1947 .

The guide further suggests that limited documentation remains prior to the foundation of the court of Protection. The Commissions themselves still exist for the years 1627 through 1932. ${ }^{62}$ These are unfortunately mainly pro forma, although in the second half of the nineteenth century they do sometimes provide an indication of the person at whose instigation the inquisition was sought. Until 1853, they are 
indexed. ${ }^{63}$ No other relevant nineteenth-century material ${ }^{64}$ appears to survive in these documentary classes, although the documents have not been completely indexed. ${ }^{65}$

Once the individual was found lunatic or idiot by inquisition, the management of his or her estate was generally committed to an individual called a 'committee', ${ }^{66}$ and their person to a guardian. Prior to the nineteenth century, members of the individual's family would generally be precluded from serving as personal guardians, as their status as potential heirs was perceived to create a conflict of interest with the lunatic's well-being. ${ }^{67}$ By the nineteenth century, this rule had disappeared, and family members were generally appointed, although the court continued to have a supervisory role. This system was considerably altered in 1853, when a formal grant of committeeship was abolished, and the individual was placed directly under court administration. ${ }^{68}$

After 1833, a finding of lunacy or idiocy by inquisition also triggered visits of the individual by Chancery Visitors. ${ }^{69}$

The Visitors included two physicians in actual practice, and a barrister of not less than five years standing. The Masters were also ex officio Visitors commencing in 1842. The frequency of visits varied over the course of the century. ${ }^{70}$ The rationale for these visits appears to have been largely to ensure proper care of the insane persons. The Public Record Office still has some administrative documents relevant to the Chancery Visitors for the nineteenth century. ${ }^{71}$ No reports of their actual visits exist, however; they were required by statute to be destroyed upon the death of the insane person, or the superseding of the Commission. ${ }^{72}$

\subsection{Other Issues of Competency}

Issues of capacity in the context of a specific will arise in probate courts, and in the context of specific contracts in the courts of common law and equity which had jurisdiction to try contractual matters. The jurisdiction of the various courts in these matters is too complicated to be dealt with 
here. Contractual litigation arose in a wide variety of courts of common law and equity, and litigation regarding wills was split between civil courts and ecclesiastical courts until 1857. Essentially, probate of real property was determined in the civil courts, and of personal property in the ecclesiastical courts. Wills concerning both realty and personalty were admitted to probate in both courts. If the will concerned small amounts of personal property in one diocese, the ecclesiastical jurisdiction would be usually be exercised in the local Bishop's court. For other estates of personalty, the matter would be heard by the Prerogative court of Canterbury or York.

The documentation concerning competency is to be found in the records of these various courts. This raises the difficulty for the researcher as to how relevant documents are to be located, from the morass of court documents remaining. There is no easy answer to this problem. One strategy would involve finding the names and dates of relevant cases in law reports, and finding the documents relevant to those cases. While this might result in a relatively direct route to relevant documentation, it has its limitations. As noted above, reported cases do not necessarily represent a balanced sample. It may in the end be the case that for at least some types of research, there is no substitute for slogging through the profusion of remaining manuscripts.

This sounds daunting but, for testamentary capacity, there are some indications that the rewards may be considerable. My brief sampling of documents from the Prerogative court of Canterbury would suggest that testamentary capacity was often raised in probate litigation in that court. The documents of that court are particularly interesting. First, the probate documents are arranged as separate classes in the Public Record office, minimizing the drudgery of scanning for relevant material. Secondly, the procedures of the ecclesiastical courts were such that much of the evidence was taken in writing, and remains in the files. Particularly in major cases, considerable amounts of interesting documentation are 
thus available. ${ }^{73}$

5. Civil Confinement

The history of the insanity defence and of the legal determination of competency centres on the study of court decisions, and thus sits at the centre of what has been traditionally thought of as history of law. Court decisions did occasionally occur regarding civil confinement, ${ }^{74}$ but they were relatively uncommon. The history of civil confinement is more a branch of the history of administrative law, where decisions were made by officials pursuant to statute, and where facilities were subject to state inspection and regulation. That said, it must be remembered that administrative law was itself in the process of formulation in the nineteenth century. ${ }^{75}$ Litigation did eventually occur as to whether the powers of Justices of the Peace to confine lunatics were judicial or administrative in nature, but not until 1899. ${ }^{76}$ For much of the nineteenth century, it is not clear that Justices themselves would have distinguished these functions.

The legal framework for civil committal, from its foundations in the eighteenth century through to the creation of the National Health Service in the mid-twentieth century, distinguished between privately paying patients and paupers. ${ }^{77}$ Until 1890, private madhouses were subject to different legislation from county asylums. There were few private patients in county asylums, and the administrative pressure from the central inspectorate, albeit not entirely successful, was against having paupers in private facilities. These distinctions were relevant for the admission processes to the facilities and the inspection jurisdiction of the central authority .

Procedures for admission to facilities were dependent on the legal status of the individual. Admission of paupers either to the asylum or the private madhouse was by order of a Justice of the Peace, although a medical certificate was also required. ${ }^{78}$ Private patients, by comparison, were until 1890 
admitted on the strength of two medical certificates and an application of a family member. ${ }^{79}$ The 1890 Lunacy Act altered these procedures by providing the private patient with a hearing before a Justice of the Peace. ${ }^{80}$ The law required that all nineteenth-century patients, whether in madhouses or county asylums, be subject to these procedures. While the madhouse acts commencing in 1853 began to allow an individual to remain in a licenced house voluntarily as a boarder following cure, ${ }^{81}$ the broader concept of voluntary admission as a patient did not receive legislative cognizance until $1930 .{ }^{82}$

In addition, a considerable number of insane persons were kept in union workhouses, largely outside the scope of the lunacy legislation. ${ }^{83}$ Until 1867, they had an ambiguous status. While apparently they were often prevented from leaving the workhouse by the union authorities, they were not legally confined under the terms of the lunacy statutes. This situation was changed by an 1867 statute, which allowed the workhouse medical officer to confine persons in workhouses under specified circumstances. ${ }^{84}$ Sadly, few records appear to remain explaining how this jurisdiction was exercised.

While processes for admission to an asylum or madhouse depended on the legal status of the individual, the applicable administrative framework depended on the type of facility. County asylums were essentially under the control of the Justices of the Peace in quarter session. Legislation in 1808 had for the first time allowed Justices to order asylum construction, and provided that it be funded by county rates. ${ }^{85}$ Even when county asylums became mandatory in $1845,{ }^{86}$ county Justices remained in control. They approved construction, and appointed from their number a management committee. It was not until 1888 that these asylums were passed over to local authority control, along with the other administrative business of quarter sessions. ${ }^{87}$ Even then, Justices retained control of admissions until 1959.

Private madhouses were privately owned, but subject to a licensing regime commencing in $1774 .{ }^{88}$ From then on, provincial houses were licensed by quarter sessions. From 1774 to 1828, 
metropolitan houses were to be licensed by a committee of the Royal College of Physicians. This was felt to be inadequate, and in 1828, the Metropolitan Commissioners in Lunacy were created. ${ }^{89}$ From 1828 into the twentieth century, this body or its successors from 1845, the Commissioners in Lunacy, ${ }^{90}$ licensed metropolitan houses.

The Commissioners in Lunacy had a broader role as well. In 1842, they conducted a national inspection of county asylums, madhouses, and some workhouses. ${ }^{91}$ This national inspection function was made permanent in 1845. In addition, increasingly over the course of the nineteenth century, the Commissioners in Lunacy received the authority to approve plans for county asylums and madhouses, advise on construction of or addition to county asylums, to ensure compliance with the legal requisites of committal, and to order the transfer of patients between facilities. For private madhouses, the Commissioners acquired the power to order the discharge of patients. It would appear that the Commissioners in Lunacy tended to rely on persuasion rather than the legal force of these powers; ${ }^{92}$ nonetheless, the powers were there.

Documentary records continue to exist both for the central authorities, and, often, at the local level as well. The lunacy statutes prescribed a variety of documents that had to be kept, including patient registers, case books, and admission documents. The following discussion will focus on the legal character of these documents. Some were intended to convince that legal standards were being met. Others had their content defined largely according to administrative order by the Lunacy Commissioners. The remarks which follow are to serve the dual purpose of introducing the range of documents available, and convincing medical historians who already work on these documents that legal historical issues are relevant to their work.

\subsection{Local Documents}

The survival of documents of local facilities is, 
predictably, a hit-and-miss affair. Occasionally, the documents of private facilities are found in private or public archive collections. ${ }^{93}$ Documents from county asylums seem more uniformly preserved. Some of these institutions are still functional, and hold their own records; others have donated their records to county record offices.

Throughout the modern period, significant care of the insane has been provided through the poor law. Until 1834, this was the responsibility of local magistrates the quarter sessions records detailing admissions to poor houses, bridewells and outdoor relief contain indications of the care of the insane in this period. ${ }^{94}$ Even after 1834, the poor law remained involved. When paupers were admitted to county asylums or, more rarely, private facilities, the bulk of the administration was handled by the poor law relieving officer, and (especially after 1853) the poor law medical officer. ${ }^{95}$ Further, as noted above, a considerable number of insane persons were kept in workhouses. Poor law union records, now generally kept in county archives, are thus also a potential source of information.

County asylums were run until 1888 by the local Justices of the Peace. Their minutes, along with those of their asylum sub-committee, will be filed with other quarter sessions documents in county record offices. The content of these minutes is a somewhat hit and miss affair. They may contain helpful information for particularly significant events, such as the construction of a new asylum, and they may well document the rules and schedules of the asylum, and discussion of employment and termination of employment of asylum staff, particularly the medical superintendent, the clerk of the asylum, the bursar and the chaplain. There does not appear to be any consistent policy as to the degree of delegation of management from the asylum sub-committee, however. In some asylums, the committee appears to have been content to leave day-to-day matters and medical treatment to the asylum staff. In others, the Justices remained influential even in the minutiae of running the asylum, and their records can be 
extremely informative. Hanwell asylum in London provides a particularly good example of such interventionist magistrates. Akihito Suzuki uses the quarter sessions papers to show that the Justices, at least as much as medical superintendent John Conolly were the instigators of non-restraint at that institution from the end of the $1830 \mathrm{~s} .{ }^{96}$ Quarter sessions records do not however tend to include a great deal of information about individual patients, where nineteenth-century admission documents and case books tend to provide more complete information.

The documents required to be kept by county asylums and private madhouses were defined by statute, and the forms can generally be found as schedules to the major acts. ${ }^{97}$ By midnineteenth century, they included admission documents, medical case books, and various registers of patients. ${ }^{98}$ In addition, there may be account books, medical journals, annual reports, report books completed by visiting Justices, Commissioners in Lunacy and poor law officials, and, for county asylums, reports between the medical superintendent and the management committee of Justices of the Peace.

Until 1890, admission of paying patients to private madhouses was largely a private affair: a reception order, coupled with two medical certificates from physicians, surgeons, or apothecaries was sufficient to result in an individual's committal. All the same, these documents were effectively required to make out a case for the committal. The application itself was primarily personal details, but did require a statement of treatment history, and duration and supposed cause of existing attack. By 1853, the form of the medical certificate required the medic to examine the alleged lunatic personally, and to specify both the facts observed which indicated insanity, and also the facts communicated by another party. ${ }^{99}$

All these forms were scrutinized by the Commissioners in Lunacy, who might apply pressure for the release of a person confined on improper documentation. These are thus not merely medical reports; they are also legal documents stating a case 
for confinement, to an administrative tribunal. This is even clearer regarding pauper patients. They could be admitted only upon the authority of a Justice of the Peace, and the application and medical certificate can therefore be understood as a submission convincing the Justice to sign the order. ${ }^{100}$

The argument for the legal nature of medical case books is twofold. First is a parallel argument to the admission documents. The readers of the case books included not merely the medical superintendent of the facility, but also the Commissioners in Lunacy, and, where applicable, the Visiting Justices (for county asylums and provincial madhouses). The intervention of these officials could result in the discharge of the patient, and the case books can thus be seen in part as indicating the medical superintendent's re-enforcement of the appropriateness of the committal. ${ }^{101}$

Secondly, the content of the medical case book was legally defined. Where statutes defined the content of admission documents, case books were required to comply with a long directive from the Commissioners in Lunacy. Consistent with a Benthamite streak in nineteenth-century administration, the case books were to keep particulars 'in a manner so clear and distinct, that they may admit of being easily referred to, and extracted, whenever the Commissioners shall so require'. ${ }^{102}$ Personal details, appearance, symptoms, and history were to be recorded in specified detail. The form does appear to have been influential. My own research does show departures from this standard, but these were largely consistent with the aim of reenforcing the appropriateness of the committal as described above. ${ }^{103}$

The point here is not that these medical records are irrelevant to understanding the development of psychiatric science. Medical men presumably acted in the utmost good faith in their completion. They did so, however, in a legal context, which must be taken into account in assessing the documents.

\subsection{Documents of the Central Authorities}


Medical historians are well aware of the existence of the central commissioners (although the records of the Poor Law Commissioners tend to be overlooked in favour of those of the Lunacy Commission). Both sets of commissioners left considerable archives. These records, like those of the doctors discussed above, are not merely medical records, but records in an administrative law context. That context, tremendously important to their nature and structure, must be addressed in order that a full picture of the records may be obtained.

The records of both the Commissioners in Lunacy and the Poor Law Commissioners are held in the Public Record Office at Kew. The collections for both are extensive, and include minutes of meetings, reports of visits, correspondence with local officials and with each other, legal opinions, collections of circular letters and orders, and reports of special inquiries. These records have their advantages. They are often indexed by the nineteenth-century clerks, and they are extensive in their range. These same factors are also their disadvantages, however: the indices are not entirely reliable, and not designed with the interests of twenty-firstcentury historians in mind. At the same time, the sheer quantity of paper makes systematic study without relying on indices an onerous task. This is less of a problem for persons engaged in local studies, since correspondence with local officials is organized geographically.

The Commissioners in Lunacy were a mixed crew of barristers, physicians, and laity, representing both utilitarian and evangelical ideologies. Appointments might be made according to either expertise or patronage. Samuel Gaskell, for example, was a former superintendent of the Lancaster Asylum and co-founder of the Association of Medical Officers of Asylums and Hospitals for the Insane, the organization which after considerable permutation became the Royal College of Psychiatrists. ${ }^{104}$ At the other extreme, Dr. Herbert appears to have had almost no specialist knowledge; his chief qualification for becoming a commissioner in 1858 appears 
to have been that he was physician to the Lord Lieutenant. ${ }^{105}$

The inclusion of both doctors and lawyers as Commissioners in Lunacy provides a tantalizing opportunity to examine how legal and medical perspectives interacted, in the development of policy. Unlike the contexts of the criminal trial and the finding of civil incompetency, where medical perspectives had to gain acceptance in fields already occupied by judges and barristers, the Commissioners in Lunacy included both doctors and lawyers from the beginning, suggesting a more level playing field between the two discourses. While this approach has its appeal, it is not without its limitations. The number of commissioners was small enough, the pressures to co-operate strong enough, and the variety of legal and medical approaches current great enough, that the views of 'legal' and 'medical' commissioners cannot easily be typified. The situation is further complicated by the importance of other themes in administrative history, such as the degree of administrative centralization that was appropriate and the tensions among Benthamism, a belief in market forces, and evangelicalism, cutting across professional lines. ${ }^{106}$

The Poor Law Commissioners present a somewhat different set of issues. Certainly, they were not necessarily unsympathetic to medical perspectives. The other co-founder of the Association of Medical Officers of Asylums and Hospitals for the Insane, Samuel Hitch, was on the staff of the Poor Law Commission commencing in the early 1840s. While issues of lunacy were not central to the Commissioners' work, a voluminous correspondence with local unions on the subject did develop. The theoretical problem at the base of the Poor Law Commissioners' work was how asylums and the treatment of the insane were to be understood in the context of the broader statutory regime created by the introduction of the New Poor Law in 1834. It is therefore less a question of competing professional ideologies, although that is certainly present as poor law medical officers worked to promote the medical perspective in the poor law, and more a question of how competing legal frameworks are to be reconciled. ${ }^{107}$ 
In the twentieth century, the tendency is to take regulatory structures for granted. It must be emphasized that such a view is entirely inappropriate in considering the nineteenth century. For both central authorities, continued existence was a tenuous matter. Centralized authority was highly controversial at the local level, and the behaviour of both sets of commissioners is to be understood accordingly. The legal power of the Commissioners to effect change was firmly limited. Exercise of even these limited legal powers in a high-handed way would carry significant political costs, and might be counter-productive in the longer term. There was a pressure on the commissioners to be ingratiating in communications with local authorities. Similarly, their annual and special reports cannot be divorced from this political culture: these reports had to convince the funder that a good job was being done. These pressures permeated the work of the central authorities; it is ill-advised to take their statements as in any way 'objective', or divorced from this political, legal and constitutional context.

\section{Conclusion}

Far from being the new kid on the block, law has been concerned with madness for centuries. While the insanity defence and the confinement of the insane are of course important sites of that concern, the legal interest in madness extends throughout the legal realm, both in the court structure and in the plethora of documents defining and articulating legal relations. The documents discussed above provide opportunities to the historian to juxtapose the theoretical conceptions of madness articulated by law and medicine. The conceptions are not (or at least not always) antagonistic. often, legal and medical approaches interact in co-operative ways, raising the question of whether they should be considered two histories or one.

This complexity of legal and medical relations exists not merely on a theoretical, but also on a practical level. 
Certainly, there are cases of legal and medical antagonism; but the nineteenth century shows equally increasing reliance of the law on doctors and of doctors on the law. The pragmatics of these relations call into question the neat divisions between legal and medical history. When for example poor law medical officers invoked the terms of the Lunacy Acts to press for the assistance of the poor law central authorities against local guardians, as they did in the 1860s, the lines between legal and medical history become refreshingly indistinct. Certainly, this was in part an attempt to develop their local employment conditions, but equally it can be read as a move towards professionalization of the care of the insane. For the central authorities, it was in part about the provision of good medical care for the insane poor, but equally about the formation of alliances to buttress the precarious political position of the central authority, a matter of constitutional debate. Reference to legal sources, and acknowledging the legal significance of sources to which reference is already made, allows consideration of new levels of complexity in the history of lunacy.

The legal history of madness remains understudied. Valuable work has been done on the history of criminal insanity, and work is beginning to appear regarding confinement in private madhouses and county asylums. The insights gained therein have not, by and large, been extended into the civil issues of competency determination nor have relations between law and medicine been theorized outside the context of criminal insanity. The documents are readily available: it is a discipline waiting to happen.

\section{Appendix I: Treatises}

Archbold. The Law Relating to Lunacy (London: 1854)

Additional editions in 1877 (ed. W.C. Glen and A. Glen), 1890 and 1895 (ed. S.G. Lushington), and 1915 (ed. J.W. Grieg and W.H. Gattie). Annotated asylum acts, including rules made pursuant to the acts. 
Brydall, John. Non Compos Mentis: Or the Law Relating to Natural Fools, Mad-Folks and Lunatick Persons (London: 1700). For indication of law prior to nineteenth century. Essentially a question and answer format, focussing on civil capacity and inquisitorial process.

Elmer, Joseph. The Practice in Lunacy under Commissions and Inquisitions (London: 1844). Seven editions by 1892. Focusses on the inquisitorial process. Somewhat legalistic in style. Includes relevant statutes.

Fry, Danby. The Lunacy Acts, (London, 1864). Very usefully brings all relevant statutes together into one place, with liberal although somewhat legalistic annotations. Includes introductions on inquisitorial matters, civil confinement, and criminal law. Limited to statutes; thus no discussion of testamentary or contractual capacity, insanity defence. Not to be confused with similar work of same name by the same author published in 1854, which is not as comprehensive.

Highmore, A. Treatise on Law of Idiocy and Lunacy (London, 1807). Shows the state of the law immediately prior to the introduction of county asylums. Particularly strong on inquisitorial process and other civil capacity, but also some discussion of criminal responsibility.

Pitt-Lewis, G., Percy Smith, and J.A. Hawke. The Insane and the Law (London, 1895). Good general text, including civil detention, civil capacity, inquisitorial issues, and criminal insanity. Designed in part for medical readership, therefore not as legalistic as some other texts.

Pope, H.M.R. A Treatise on the Law and Practice of Lunacy (London, 1877). Second edition, 1892. One of the classic texts. Somewhat legalistic. 
Renton, Alexander $\mathrm{W}$. The Law and Practice of Lunacy (Edinburgh and London, 1896). Concerns civil competency and crime only; not inquisitorial process. Very detailed and helpful for specific points of law, but legalistic and probably intimidating to the neophyte.

Sabben, James T., and J.H. Balfour Browne. Handbook on Lunacy and Law (London, 1872). Written by a physician and a barrister for a medical readership, this is a very straightforward discussion of procedures for examining and completing required documentation, including samples of forms appropriately completed. Discussion centres on civil confinement and inquisitorial process, to the exclusion of criminal matters.

Shelford, Leonard. A Practical Treatise of the Law concerning Lunatics, Idiots, and Persons of Unsound Mind (London, 1833). Second edition: 1847. Good, general, mid-century text. 
Note: while most abbreviations are reasonably standard, some variations do occur. In addition, some reports have similar names. The following list does not include the large number of private reports re-printed in the 176-volume English Reports. A list of those abbreviations is contained in the first volume of those reports and generally on a wall chart located near those reports in law libraries. When in difficulty, check with library staff.
A. C.
Appeal Cases

All E.R.

All England Reports

C.C.C.

Cox's Criminal Cases

Ch.

Chancery Reports

Cr.App.R.

Criminal Appeal Reports

Ex.

Exchequer Reports (or Exch.)

Fam.

Family Reports

H.L.

House of Lords Cases (or L.R.H.L.)

Howell's St.Tr. Howell's State Trials

J.P.

Justice of the Peace Reports

K.B.

King's Bench Reports

L.T.

Law Times Reports

LJ Ex

Law Journal (Exchequer Cases)

$\mathrm{LJ} \mathrm{MC}$

Law Journal (Magistrates Cases)

$\mathrm{LJ} \quad \mathrm{QB}$

Law Journal (Queen's Bench Cases)

[LJ (NS) indicates the second series of Law Journal reports.]

$\mathrm{P}$.

Probate Reports

P.C.

Privy Council Cases (or L.R.P.C.)

Q.B.

Queen's Bench Reports

St.Tr.

State Trials

T.L.R.

Times Law Reports

W.L.R.

Weekly Law Reports

"M.A., LL.B., Ph.D., of the Bar of Ontario. Senior

Lecturer, School of Law, University of Nottingham. My thanks to Stephen Girvin, David Wright and Alan Yoshioka for 
commenting on drafts of this article.

${ }^{1}$ De Prerogativa Regis, 17 Edw. II, stat I, (1324).

${ }^{2}$ See Ontario, Ministry of Health, Enquiry into Mental Competence, (Toronto, 1990) p. 324; G. Robertson, Mental Disability and the Law in Canada (Toronto, 1987) p. 8; N.A. Heywood and A.S. Massey, Court of Protection Practice, 9th ed., D.G. Hunt and M.E. Reed (eds.), (London, 1971).

${ }^{3}$ It is not until 1991 that a jury was required following a finding of unfitness to plead to determine whether the accused even did the act they were accused of: see Criminal Procedure (Insanity and Unfitness to Plead) Act 1991, s. 2. Even this amendment does not allow defences to be raised, in the event that the accused is found to have committed the act in question.

${ }^{4}$ As an example of this sort of approach in the eighteenth century, see M. MacDonald, 'Lunatics and the state in Georgian England', Social History of Medicine, 2 (1989), 299-313, which examines breaches of trust and corruption in the administration of estates of lunatics by the court of Chancery.

${ }^{5}$ See P. Bartlett, The Poor Law of Lunacy, (London, 1999), pp. $174-7$.

${ }^{6}$ See, for example, the German Burgerliches Gesetzbuch, paras. 6 and 1910, concerning guardianship and curatorship. This is a descendant of the cura furiosi in the Twelve Tables. See expecially I.1.23.3.4 (Justinian). I thank Dr. Stephen Girvin for this genealogy. Regarding the development of this approach in post-revolution France, see R. Castel, The Regulation of Madness, (Oxford, 1988).

(1) and (3).

78 \& 9 Vic. C. 126, sch. E (1); 16 \& 17 Vic. C. 97, sch. F

${ }^{8}$ Banks v. Goodfellow (1870), 5 Q.B. 549, p. 565.

${ }^{9}$ This point is made, for example, in Akihito Suzuki's study of nineteenth-century parens patriae cases: 'Enclosing and disclosing lunatics within the family walls: domestic psychiatric regime and the public sphere in early nineteenthcentury England', in P. Bartlett and D. Wright (eds.), Outside the Walls of the Asylum, (London, 1999), 115-31.

${ }^{10}$ As an example of legal sources used in this way, see Suzuki, 'Enclosing and disclosing lunatics'.

\footnotetext{
11 (1822), 1 Add 229.

${ }^{12}$ Evans v. Knight, p. 238.
} 
${ }^{13}$ See for example J.P. Eigen, '"I answer as a physician": Opinion as fact in pre-McNaughtan insanity trials', M. Clark and in C. Crawford (eds.), Legal Medicine in History,

(Cambridge, 1994), 167-99. For the effect of legal structures on medical testimony more generally in this period, see C. Crawford, 'Legalizing Medicine', in the same volume, 89-116.

${ }^{14}$. Smith, Trial By Medicine, (Edinburgh, 1981) .

${ }^{15} \mathrm{P}$. Fennell, 'Law and Psychiatry: The Legal Constitution of the Psychiatric System', Journal of Law and Society, 13 $(1986), 35-65$.

${ }^{16}$ See R. Smith, 'Legal Frameworks for psychiatry', in G. Berrios and H. Freeman (eds.), 150 Years of British Psychiatry 1841-1991, 2 vols, vol. I, (London, 1991), 137-151; R. Smith, Trial By Medicine; N. Rose, The Psychological Complex, (London, 1985); C. Unsworth, The Politics of Mental Health Legislation, (Oxford, 1987).

${ }^{17}$ See R. Porter, 'History of Psychiatry in Britain', History of Psychiatry, 2 (1991), 271-9, p. 278.

${ }^{18}$ See further section 5 , below.

${ }^{19}$ See for example, Dew V. Clark (1828), 3 Add. 79; Frere v. Peacocke, 1 Rob. Ecc. 442; Waring v. Waring (1848), 6 Moore 341 and, finally, Banks v. Goodfellow. The first three of these may be particularly fertile fields for research. As they were probate cases tried in the ecclesiastical courts, considerable documentation exists for them: see further below.

${ }^{20}$ See, e.g., R. Smith, Trial By Medicine; M. Foucault, 'The Dangerous Individual', in Lawrence Kritzman (ed.), Politics, Philosophy, Culture, (New York, 1988), 121-51; J.P. Eigen, 'Delusion in the Courtroom', Medical History, 35 (1991), 25-49; and J.P. Eigen, Witnessing Insanity: Madness and Mad-Doctors in the English Court, (New Haven, 1995).

${ }^{21}$ See for example J. Walton, 'Casting out and bringing back in Victorian England: Pauper lunatics 1840-70' in W. Bynum, $R$. Porter, M. Shepherd (eds.), The Anatomy of Madness, 3 vols., vol. II, (London: 1985), 132-146; C. MacKenzie, 'Social factors in the admission, discharge, and continuing stay of patients at Ticehurst Asylum, 1845-1917', in W. Bynum et al, ibid, 147-74; D. Wright, 'Getting out of the Asylum:

Understanding the Confinement of the Insane in the Nineteenth Century', Social History of Medicine, 10 (1997), 137-56; J. Melling, W. Forsythe and R. Adair, 'The New Poor Law and the County Pauper Lunatic Asylum- the Devon Experience 1834-1884', Social History of Medicine, 9 (1996), 335-356; R. Adair, W. Forsythe and J. Melling, 'A Danger to the Public? Disposing of Pauper Lunatics in late-Victorian and Edwardian England', 
Medical History, 42 (1998), 1-25; and, regarding a somewhat earlier period, J. Andrews, 'The Politics of Committal to Early Modern Bethlem', in R. Porter, (ed.), Medicine in the Enlightenment, (Amsterdam: 1995), 6-63; P. Bartlett, The Poor Law of Lunacy; and the papers contained in J. Melling and W. Forsythe (eds.), Insanity, Institutions and Society, 1800-1914, (London, 1999).

${ }^{22}$ I.e., when the mental illness is not consequent on actual physical injury: compare Victorian Railways v. Coultas, [1888] App. C. 222 (J.C.P.C.); Dulieu v. White, [1901] 2 K.B. 669; and Hambrook V. Stokes, [1925] 1 K.B. 141 (C.A.). Note that these first two cases occurred before the popularisation of nervous shock as a concept, following the first world war.

${ }^{23}$ I.e., where the claim was that the person signing the document had completely misconstrued the nature of the document being signed, such misunderstanding being due to illiteracy, illness, or innate incapacity.

${ }^{24}$ By tradition, the year is included in square brackets if the case report recommences its volume numbers at the beginning of each year, and in round brackets if the volume numbers continue uninterrupted through the run of the case report, thus Hadfield's Case (1800), 27 Howell's St. Tr. 1281, but Hodson V. Pare [1899] 1 QB 455.

${ }^{25}$ For abbreviations of cases contained in the English Reports, see the list of abbreviations contained in the first volume of those reports. This list is also often included in chart form, near the reports in most libraries. A list of other relatively common abbreviations of case reports is contained as Appendix II. For the meaning of abbreviations not contained on these lists, researchers should consult a law librarian. 410 .

${ }^{26}$ Thus Dew v. Clark (1828) 3 Add. 79, rather than $162 \mathrm{ER}$

${ }^{27}$ Lest this not be complex enough, there are two series of Queen's Bench reports (Q.B.). Cases before 1865 are contained in the English Reports; cases after 1865 are contained in the separate and official Queen's Bench Reports series.

${ }^{28}$ Chair: E.S. Campbell, Baron Percy of Newcastle, P.P., 1956-7, XVI, 1, reprinted (London: 1957).

${ }^{29}$ The Lunacy Acts, (London, first ed. 1864; second ed. 1877; third ed., under the title Lunacy Law, 1890). An 1854 work by Fry (also called, confusingly, the Lunacy Acts) is not as comprehensive.

30 N. Walker, Crime and Insanity in England, (Edinburgh, 
$1968)$.

${ }^{31}$ Criminal Lunatics Act, 39 \& 40 Geo. III (1800), c. 94, s. 2. See also M. Hale, A History of the Pleas of the Crown, (London, 1680).

$$
32(1836), 7 \text { Car. \& P. } 304 .
$$

${ }^{33} 39 \& 40$ Geo. III, c. 94. The occasion for the passage of this legislation was Hadfield's Case, (1800) 27 Howell's St. Tr. 1281, where Hadfield's counsel had been successful at securing an acquittal. Nonetheless, insanity was pleaded as a defense well before that time: see N. Walker, Crime and Insanity in England, chapters 2 and 3, and the works by Eigen, above.

$$
\begin{aligned}
& { }^{34} \text { (1843), } 10 \mathrm{Cl} \text { \& F. } 200 . \\
& { }^{35} \text { per Chief Justice Tindal, at } 210 . \\
& { }^{36} \text { See N. Walker, Crime and Insanity in England, chapter } 8 . \\
& { }^{37} \text { See Homicide Act, } 1957,5 \text { \& } 6 \text { Eliz. II, c. 11, s. } 2 . \\
& { }^{38} \text { See for example R. Smith, Trial by Medicine; works by }
\end{aligned}
$$
Eigen, above; A. Walk, 'What We Thought About it All', in D. West and A. Walk (eds.), Daniel McNaughton: His Trial and the Aftermath, (London, 1977), 113-28.

${ }^{39}$ The most recent history of Bethlem, from its mediaeval foundation to the twentieth century, is J. Andrews, A. Briggs, R. Porter, P. Tucker and K. Waddington (eds.), The History of Bethlem, (London, 1997).

${ }^{40}$ Regarding county asylum case books, admission documents, and other records, see below. Bethlem has an active archive, and its current archivist has published a variety of papers about the institution and its inmates: see, for example, P. Allderidge, 'Why was McNaughton sent to Bethlem?', in D. West and A. Walk (eds), Daniel MCNaughton, (London, 1977), 100-12; and P. Allderidge, 'Bedlam: fact or fantasy', in W.F. Bynum, R. Porter and M. Shepherd (eds), The Anatomy of Madness, 3 vols., vol. II, (London: 1985), 17-33.

${ }^{41}$ The reporters do begin self-censoring in the late eighteenth century, regarding trials deemed too scandalous to be reported. Historians of sodomy, for example, will find some of the nineteenth-century records frustrating in this regard.

${ }^{42}$ See works of Eigen cited above. Regarding trials at the Old Bailey generally, see J. Langbein, 'The Criminal Trial before the Lawyers', University of Chicago Law Review, 45 (1978), 263-316. Langbein also relies extensively on the 
Sessions Papers. (1324).

${ }^{43}$ De Prerogativa Regis, 17 Edw. II, stat. I, CC. ix and $x$

${ }^{44}$ David N. Weisstub, chair. (Toronto, 1990) at appendix III.

${ }^{45}$ See, for example, Ex p. Barnsley (1745), 3 Atk. 164.

${ }^{46}$ See for example Ridgeway v. Darwin (1802), 8 Ves. Jun. 65, and Ex p. Cramner (1806), 12 Ves. Jun. 445.

${ }^{47}$ Idiocy as originating at birth was based at least in part in the terms of the fourteenth-century statute, through the concept of a 'natural fool': see De Prerogativa Regis, 17 Edw. II. (1324), stat I, c. 9. For the mid-nineteenth century conception, see Bannatyne and Bannatyne v. Bannatyne (1852), 2 Rob. Ecc. 472, esp. pp. 482 ff. The distinction drawn there, reflecting to some degree the earlier distinction, was that idiocy was a permanent condition, whereas lunacy allowed the possibility of a 'lucid interval'.

${ }^{48}$ Regarding delusion as the criterion of insanity, see $P$. Bartlett, 'Sense and Nonsense: Sensation, Delusion and the Limitation of Sanity in Nineteenth-Century Law', in L. Bently and L. Flynn (eds.), Law and the Senses (London, 1996), 21-41.

${ }^{49}$ Thus for example Jenkins v. Morris, (1880) 14 Ch. D. 674 was a case in which an individual was subject to a delusion that his land was polluted with sulphur. He leased it at a rate which would have been advantageous to him if the land had been so polluted, but not otherwise. The court held that, notwithstanding his delusion, he had the required mental ability to sign the lease. Thus Jessel M.R. holds expressly that 'although a man may believe a farm to be impregnated with sulphur and not fit for himself to live in, he may still be a shrewd man of business' [p. 683]. For further cases demonstrating the movement away from delusion as the test of insanity and incompetence, see Birkin v. Wing (1890), 6 L.T. 80 and Imperial Loan Co. V. Stone (1892), 1 Q.B. 599. For an example of the older test based on delusion, see Dew v. Clark pp. $92-3$.

${ }^{50}$ By 1824, the physician Alexander Morison no longer considered idiocy and imbecility necessarily to begin at or near birth: see J. Saunders, 'Quarantining the weak-minded', in W. Bynum, R. Porter and M. Shepherd (eds.), The Anatomy of Madness, 3 vols., vol. III, (London, 1988), 273-96, p. 274.

${ }^{51}$ Regarding the origins of the Royal Prerogative power, see Richard Neugebauer, 'Mental Handicap in Medieval and Early Modern England', in D. Wright and A. Digby (eds.), From Idiocy 
to Mental Deficiency, (London, 1996), 22-43. For an assessment of the use of the orders in a nineteenth-century social context, see A. Suzuki, 'Englosing and disclosing lunatics'. Regarding the care of the insane after the issuance of a commission, see M. MacDonald, 'Lunatics and the State'.

${ }^{52}$ See Beverley's Case, (1603) 4 Co. Rep. 123 at 126, and B. Hoggett, 'The Royal Prerogative in Relation to the Mentally Disordered', in M.D.A. Freeman (ed.), Medicine, Ethics and the Law, (London, 1988), 85-102, p. 90.

${ }^{53} \mathrm{~A}$ finding of lunacy by inquisition was not irrelevant to the committal process, however. The Commissioners in Lunacy had the authority to order the release of persons detained in private madhouses without due cause: see further below. These discharge provisions did not extended to those found lunatic by inquisition: see, for example, 53 Vic. (1890), c. 5, s. 78(7).

${ }^{54}$ See, for example, Prinsep and East India Co. v. Dyce Sombre (1856), 10 Moore 232 (J.C.P.C.) pp. 239, 245.

${ }^{55}$ The Court of Appeal in In Re Walker, [1905] 1 Ch. 160 that the issue of a Commission precluded the subject from contracting until the Commission were superseded. For an earlier contrary authority, see M'Adam V. Walker (1813), 1 Dow. $148 \mathrm{pp}$. 177-8, which held (albeit tangentially) that a contract signed during a lucid interval would be binding, even if a Commission were in effect at the time the contract was signed.

${ }^{56}$ In 1660, by 12 Charles II c. 24.

${ }^{57}$ Theoretically, responsibility for the Royal Prerogative was by appointment under the Sign Manual, and separate from the Chancellor's position until 1874. It was at that time moved formally to the Lord Chancellor's jurisidiction under the Great Seal Offices Act, 1874, 37 \& 38 Vic. c. 405. This legal trivia occasionally affected legal drafting, but is of minimal importance otherwise, since the Chancellor always was the appointee. This process disappears with the passage of the Mental Health Act 1959, which placed care of the person and property of those lacking capacity on an entirely statutory footing.

${ }^{58}$ Not to be confused with the Metropolitan Commissioners in Lunacy, created in 1828 with the responsibility of inspecting and licensing private madhouses in greater London. The same legislation which altered the name of the (pre-1845)

Commissioners in Lunacy to 'Masters in Lunacy' also gave the Metropolitan Commissoners a national inspection role and renamed them, confusingly, the 'Commissioners in Lunacy': see 8 \& 9 Vic. (1845) C. 100, ss. 2 and 3. Regarding this other sort of Commissioners in Lunacy, see further below. For clarity in 
this paper, the term 'Masters in Lunacy' will be used for those involved in proceedings related to the Royal Prerogative, but it should be recognized that before 1845, this is an anachronism.

${ }^{59}$ See 5/6 Vict. c. 84 (1842). The trial of contested proceedings was returned to judicial control in 1890: v. 53 Vict. c. 5, part III.

$$
{ }^{60} 3 \text { \& } 4 \text { William IV (1833) c. } 36 .
$$

${ }^{61} 16 / 17$ Victoria c. 70 (1853) s. 38. For inquisitions conducted after 1853, this statute provides a convenient consolidation of law.

${ }^{62} \mathrm{PRO} \mathrm{C} 211,75$ bundles.

${ }^{63} \mathrm{PRO}$ IND 17612. This index shows the name and address of the subject, and the date of the Commission.

${ }^{64}$ See, however, PRO C217/55, regarding lunacy proceedings between 1719 and 1733 .

${ }^{65} \mathrm{PRO} \mathrm{C} 217$ is partially indexed in List and Index Society vol. 25. Apart from bundle 55, noted above, this class appears to contain only documents related to the functions of the office regarding admission of solicitors to practice and bankruptcy. Bundles 123 to 165 are shown only as

'Miscellaneous documents', however.

\section{${ }^{66}$ Pronounced with accents on first and third syllable; i.e., one to whom management of the estate is committed.}

${ }^{67}$ Some sources actually cite the desirability of potential heirs acting as committees of the estate, since their interest like that of the lunatic would be in its preservation, while dependents other than heirs would be made guardians of the person, since they had a direct interest in the lunatics continued physical well-being.

${ }^{68} 16$ \& 17 Vic., c. 70. Families remained heavily involved, of course, but the actual decisions passed to the Masters in Lunacy regarding estates, and to the Chancery Visitors regarding the person: see further below.

${ }^{69}$ Not to be confused with official visitors (Justices of the Peace or Lunacy Commissioners, depending on the facility) under madhouse acts or county asylum acts.

${ }^{70}$ The 1833 statute required annual visitation: 3 \& 4 Will. IV (1833) c. 36, s. 2. This was increased to quarterly in 1862, and reduced quarterly in the first two years of the commission and semi-annually thereafter in 1882: 25 \& 26 Vic. 
(1862), c. 86, s. 20; 45 \& 46 Vic. (1882), c. 82, s. 4. Visits were less frequent if the individual was in a private madhouse, and thus subject to other official visits. Each visit was to have at least one medical and at least one legal Visitor present.

${ }^{71} \mathrm{PRO}$ LCO 1,2 , and 4 is the correspondence between the Masters in Lunacy and the Chancery Visitors, often containing comment about proposed legislation and copies of revisions to rules under the Acts. PRO LCO 9 are the minutes of meetings of the Chancery Visitors. While these minutes give minimal detail regarding individual patients, they do provide an indication of the sorts of decisions the Visitors were involved in, e.g., leaves of absense of patients from asylum, agreements to move individuals between asylums, etc.

${ }^{72}$ See, for example, 16 \& 17 Vic. (1853), c. 70, s. 107; 53 Vic. $(1890)$, c. 5, s. 186.

${ }^{73}$ The probate allegations are contained in PRO PROB 18, at the Public Record Office. There is a card index of this class in the Public Record Office, organised by both name of deceased and name of the case. The documents in PROB 18 can be used to identify those cases where testimentary capacity was challenged. Answers to the allegations are filed in PRO PROB 25. Answers are organized by date. Exhibits are contained in PRO PROB 31. The card index to this class appears to include only inventories of property, and will therefore not be complete for those interested in issues of capacity. A better index to this class is contained in PRO PROB 33. Indices on open shelves in the PRO provide a key between numbering in the original documentation and the bundle and piece numbers in the Public Record Office.

Particularly voluminous cases are not contained in these series, but separately in PRO PROB 26 (depositions) and PROB 37 (cause papers). A number of these cases concern issues of capacity, including Frere v. Peacocke, Evans v. Knight, Prinsep and East India Co. V. Dyce Sombre, Waring v. Waring, and Bannatyne $\mathrm{v}$. Bannatyne. These matters are not contained in the indices to $\mathrm{PROB}$ 18, noted above, but are contained in the index volumes on open shelves in the PRO.

${ }^{74}$ Particularly common were cases involving disputes as to which poor law union was liable for the maintenance of a pauper lunatic. Such of these as were reported are usually contained in Law Reports (New Series) Magistrates' Cases, which is indexed by volume. Less frequent were wrongful confinement cases involving private madhouses. The precedent-making cases are referred to in the legal treatises cited in appendix I.

${ }^{75}$ For general discussion, see H. Arthurs, Without the Law, (Toronto, 1985). 
${ }^{76}$ Hodson v. Pare, [1899] 1 Q.B. 455 (C.A.).

${ }^{77}$ The scope of the term 'pauper' in this context has been the subject of some debate. Ruth Hodgkinson for example argues that the term in the context of civil insanity included a broader category of people than would be within the aegis of the new poor law: Origins of the National Health Service, (London, 1967), chapter 10. This perception was shared at least sometimes by the Commissioners in Lunacy: see their Ninth Annual Report, P.P., 1854-5, XVII, 533 at 34 . For a more sceptical view, see P. Bartlett, The Poor Law of Lunacy, pp. $41-3,157-8,204-5$.

${ }^{78}$ Under unusual circumstances, an officiating clergyman and a relieving officer acting jointly could also order the admission of a pauper lunatic to one of these facilities.

${ }^{79}$ Idiot children admitted pursuant to the Idiots Act 1886 required only one medical certificate, along with the order for admission signed by the parent or guardian: 49 Vict. c. 25, s. 4 .

${ }^{80} 53$ Vic., C. 5, s. 4.

${ }^{81} 16$ \& 17 Vic., c. 96, s. 6. In 1863, this provision was expanded to allow facilities to keep as boarders those discharged from any madhouse or asylum within the previous five years: 25 \& 26 Vic., c. 111, s. 18.

${ }^{82}$ Mental Treatment Act, 1930, 20 \& 21 Geo. V, c. 23, s. 1.

${ }^{83}$ Throughout the second half of the nineteenth century, during the explosion of county asylum construction, a fairly steady twenty-five per cent of the insane poor were in workhouses. The proportion of insane poor on outdoor relief did decline in this period, from roughly twenty-five to roughly eight per cent: see Bartlett, Poor Law of Lunacy.

${ }^{84} 30$ \& 31 Vic., c. 106. In the same year, statutory provision was made for the building of lunatic asylums under the aegis of the poor law, in London: see 30 Vic., c. 6.

${ }^{85} 48$ Geo. III, C. 96.

${ }^{86}$ Pursuant to 8 \& 9 Vic., c. 126.

${ }^{87}$ This business included not only asylum management, but some police administrative functions, administration of county buildings, lock-ups, police stations, and court houses, reformatory and industrial schools, public health functions, control of public nuisances and pollution, and some control over poor law funding: V. 51 \& 52 Vict. c. 41 (1888). Regarding asylums specifically, see s. 3(vi), 86, 111. 
${ }^{88} 14$ Geo. III, C. 49.

${ }^{89} 9 \mathrm{Geo} . \mathrm{IV}, \mathrm{C} .40$.

${ }^{90}$ Not to be confused with the prior body called 'Commissioners in Lunacy', who became 'Masters in Lunacy' under the 1845 legislation: see further above.

${ }^{91}$ Pursuant to 5 \& 6 Vic. (1842), c. 87.

${ }^{92}$ See N. Hervey, 'A slavish bowing down: The Lunacy Commission and the psychiatric profession 1845-60', in W. Bynum, R. Porter and M. Shepherd (eds), The Anatomy of Madness, 3 vols., vol. II, (London, 1985), 98-131; and P. Bartlett, The Poor Law of Lunacy, chapter 6. For, perhaps, a different view, see B. Forsythe, J. Melling and R. Adair, 'Politics of lunacy: central state regulation and the Devon Pauper Lunatic Asylum, 1845-1914', in J. Melling and B. Forsythe (eds.), Insanity, Institutions and Society, 1800-1914, (London, 1999), 68-92; and D. Mellett, 'Bureaucracy and Mental Illness: the Commissioners in Lunacy, 1845-90', Medical History, 25 (1981), $221-50$.

${ }^{93}$ Thus, for example, the records of Ticehurst Asylum are lodged in the library of the Wellcome Institute for the History of Medicine in London. For a discussion of those records, see C. Mackenzie, Psychiatry for the Rich: A History of the Private Ticehurst Asylum, 1792-1917, (London, 1992). The records for Hook Norton and Witney private madhouses are in the Oxfordshire County Record Office: see W. Parry-Jones, The Trade in Lunacy, (London, 1972). The records of the York Retreat remain at that institution, and are discussed by A. Digby in Madness, Morality and Medicine: A Study of the York Retreat, 1796-1914, (Cambridge, 1985).

${ }^{94}$ For the use of eighteenth-century Quarter Sessions records, see A. Suzuki, 'Lunacy in seventeenth- and eighteenthcentury England: Analysis of Quarter Sessions records', History of Psychiatry, 2 (1991), 437-56 and History of Psychiatry, 3 (1992), 29-44.

${ }^{95}$ Prior to 1853 , the poor law medical officer had been precluded from completing the medical certificate required for the committal of the pauper. The duty of poor law medical officers to visit quarterly lunatics not in asylums commenced in 1845: 8 \& 9 Vic., c. 126, s. 55.

${ }^{96}$ A. Suzuki, 'The Politics and Ideology of Non-Restraint: the Case of the Hanwell Asylum', Medical History, 39 (1995), $1-17$.

${ }^{97}$ See, for example, schedules to An Act for the Regulation 
of the Care and Treatment of Lunatics, 8 \& 9 Vict. (1845), c. 100; An Act to amend the Laws for the Provision and Regulation of Lunatic Asylums for Counties and Boroughs, and for the Maintenance and Care of Pauper Lunatics, in England, 8 \& 9 Vict. (1845), c. 126; An Act to amend an Act passed in the Ninth Year of Her Majesty, 'for the Regulation of the Care and Treatment of Lunatics', 16 \& 17 Vict. (1853), c. 96; and The Lunatic Asylums Act, 1853, 16 \& 17 Vict. c. 97. The asylum case books were an exception. They were prescribed by administrative order of the Lunacy Commission, rather than by statute.

${ }^{98}$ For a discussion of the use of county asylum records, see P. Bartlett, The Poor Law of Lunacy, chapter 5; D. Wright, 'Getting Out of the Asylum' pp. 149-154; W. Forsythe, J. Melling and R. Adair, 'The New Poor Law and the County Pauper Lunatic Asylum'. Regarding the use of very similar documents from a private facility, see D. Wright, 'Childlike in his Innocence', in D. Wright and A. Digby (eds.), From Idiocy to Mental Deficiency, (London, 1996) 118-133.

${ }^{99}$ See 16 \& 17 Vic., c. 96, sch. B, no. 2. The act provided that no committal could be justified only by facts communicated to the medic: s. 10 .

${ }^{100}$ For nineteenth-century discussions of how the medical certificates could be completed to the satisfaction of the Lunacy Commissioners, see J. Bucknill, 'The Medical Certificates of Admission Papers', Journal of Mental Science, 4 (1858), 312-7; and J. Sabban and B. Browne, Handbook of Law and Lunacy, (London, 1872).

${ }^{101}$ The poor law officials did not have the legal power to discharge patients in county asylums; but as the persons controlling payment for the detention of paupers, they had considerable influence regarding continued detention.

${ }^{102}$ The Commissioners did publish a summary of asylum treatment techniques and efficacy as an appendix to their 1847 Supplementary Report, P.P., 1847, in octavo 1847-8, XXXII, 371.

${ }^{103}$ See P. Bartlett, Poor Law of Lunacy, chapter 5.

${ }^{104}$ A biography of Gaskell is contained in A. Scull, C. MacKenzie and N. Hervey, Masters of Bedlam, (Princeton, 1996), chapter 6 .

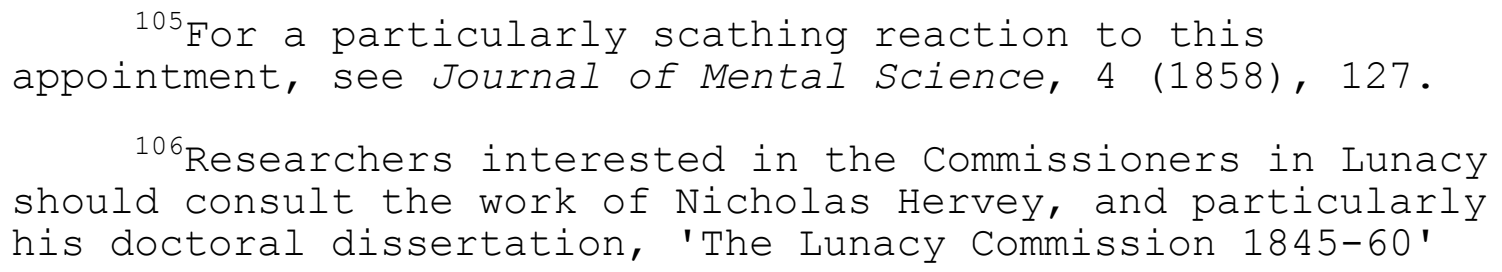


(diss. University of Bristol, 1987). Of necessity less detailed, but more readily available, is his paper 'A slavish bowing down'. See also P. Bartlett, The Poor Law of Lunacy, chapter 6; B. Forsythe, J. Melling and R. Adair, 'Politics of lunacy', and D. Mellett, 'Bureaucracy and Mental Illness'.

107 See Bartlett, Poor Law of Lunacy, chapter 3 and pp. 213-24; Bartlett, 'The asylum and the Poor Law: the productive alliance', in J. Melling and B. Forsythe (eds.), Insanity, Institutions and Society, 1800-1914, (London, 1999), $48-67$. 